\title{
An azobenzene container showing a definite folding - synthesis and structural investigation
}

\author{
Abdulselam Adam, Saber Mehrparvar and Gebhard Haberhauer ${ }^{*}$
}

\author{
Full Research Paper \\ Address: \\ Institut für Organische Chemie, Universität Duisburg-Essen, \\ Universitätsstr. 7, D-45117 Essen, Germany \\ Email: \\ Gebhard Haberhauer * gebhard.haberhauer@uni-due.de \\ * Corresponding author \\ Keywords: \\ azobenzene; macrocycles; molecular switch
}

Beilstein J. Org. Chem. 2019, 15, 1534-1544. doi:10.3762/bjoc. 15.156

Received: 15 April 2019

Accepted: 25 June 2019

Published: 10 July 2019

This article is part of the thematic issue "Novel macrocycles - and old ones doing new tricks".

Guest Editor: W. Jiang

(C) 2019 Adam et al.; licensee Beilstein-Institut.

License and terms: see end of document.

\begin{abstract}
The combination of photo-switchable units with macrocycles is a very interesting field in supramolecular chemistry. Here, we present the synthesis of a foldable container consisting of two different types of Lissoclinum macrocyclic peptides which are connected via two azobenzene units. The container is controllable by light: irradiation with UV light causes a switching process to the compact cis,cis-isomer, whereas by the use of visible light the stretched trans,trans-isomer is formed. By means of quantum chemical calculations and CD spectroscopy we could show that the trans $\rightarrow$ cis isomerization is spatially directed; that means that one of the two different macrocycles performs a definite clockwise rotation to the other, caused by irradiation with UV light. For the cis $\rightarrow$ trans isomerization counterclockwise rotations are found. Furthermore, quantum chemical calculations reveal that the energy of the cis,cis-isomer is only slightly higher than the energy of the cis,trans-isomer. This effect can be explained by the high dispersion energy in the compact cis,cis-isomer.
\end{abstract}

\section{Introduction}

In supramolecular chemistry rigid scaffolds are required to arrange different recognition units in predefined distances and spatial orientation to each other [1]. One example for such rigid systems are macrocycles which stem from Lissoclinum cyclopeptide alkaloids (Figure 1) [2,3]. Here, the required recognition units can be introduced via the amino acid side chains or via the side chains of the azole rings. The orientation and the distance between the recognition units are determined by the type and size of the macrocyclic platform, e.g., if all of the amino acid side chains are of the same configuration, they are presented on one face of the macrocycle in a convergent manner. The artificial Lissoclinum cyclopeptide platforms feature $C_{2}, C_{3}$ and $C_{4}$ symmetry [3]. So far, a series of receptors based on these macrocycles were synthesized. They have been designed for the selective recognition of sulfate ions [4-6], diand triphosphate ions [7], for sensing of pyrophosphate ions in 


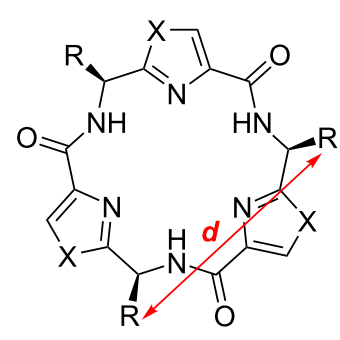

$1 \mathbf{a}(X=S, O)$

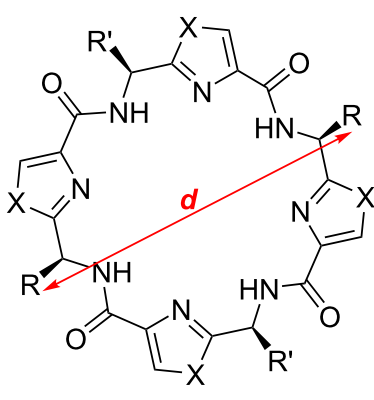

1b $(X=S, O)$

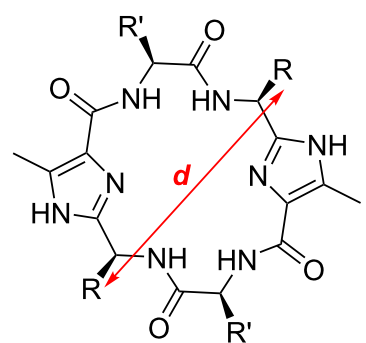

2

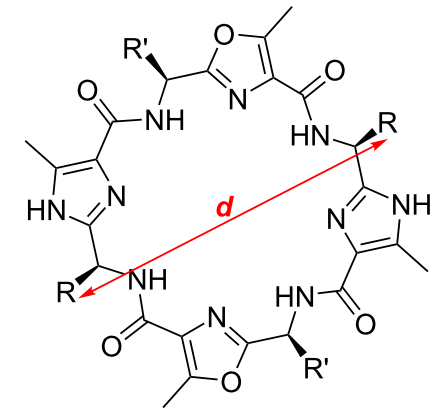

3

Figure 1: Some examples for artificial $C_{2}$ and $C_{3}$-symmetric platforms based on Lissoclinum cyclopeptide alkaloids.

aqueous solutions [8], as receptors for phenols [9], $\alpha$-chiral primary organoammonium ions [10], and biomolecules [11-17]. Furthermore, modified Lissoclinum cyclopeptides were used for the construction of novel tubular and cage structures [18,19], as prototypes for mimicking multiple loops of proteins [20] and for homochiral supramolecular polymerization [21,22]. Beside the usage of the side chains of the amino acids and the azole rings for molecular recognition, the functional groups of the scaffolds of these cyclopeptides have also been applied as receptors for $\mathrm{Y}$-shaped anions [23] and as ligands for copper(II) complexes [24,25].

Of special interest is the design of artificial Lissoclinum cyclopeptides which can be switched by the incorporation of a suitable switching unit into the scaffold. A switching process would allow to vary the orientation and the distance between the recognition units. Examples for such switching units are photochromic molecules which can be reversibly changed between two isomers of different structures [26-29]. One prominent switching unit is azobenzene and its derivatives [30-41] The trans-isomer features a stretched and the cis-isomer has a compact geometry. In general, the trans $\rightarrow$ cis isomerization is triggered by UV light whereas the cis $\rightarrow$ trans back relaxation takes place by visible light or heat $[30,42]$. Due to the high reversibility, the simple synthesis and the high photostability azobenzene derivatives are the most commonly used switching units. A further advantage of the use of azobenzene as switching unit is the fact that it is possible to control the conformation of the cis or the trans-isomers by chiral bridges [43-48].

Up to now two artificial Lissoclinum cyclopeptides, which feature an azobenzene moiety to change the distance between the amino acid side chains, are described in the literature [49,50]. One example is the platform 4 , which consists of two imidazole building blocks connected by two azobenzene units (Figure 2) [50]. Irradiation of the platform 4 with UV light results in a trans $\rightarrow$ cis isomerization accompanied by a reduc- tion of the distance between the two isopropyl groups. As further example the chiral foldable container 5 should be mentioned [49]. Here, two imidazole-containing macrocycles are linked to each other by two azobenzene units (Figure 2). Irradiation with UV light causes two consecutive trans $\rightarrow$ cis isomerization's resulting in a stepwise decrease of the distance of the two macrocycles. Accordingly, the distance between the recognition units at the upper and the lower macrocycle decreases stepwise as well.

In the chiral container 5 two identical macrocycles are connected to each other. A further development would be a foldable container featuring two different macrocycles which allows to distinguish between the upper and the lower part of the container. Here, we present the synthesis and the structural investigation of a switchable chiral container in which two different $C_{2}$-symmetric artificial Lissoclinum cyclopeptides are connected by two azobenzene bridges. A light-induced switching process leads to a spatially directed collapse of the container which can be detected by an increase of the diffusion coefficient of the molecule.

\section{Results and Discussion \\ Synthesis of the chiral foldable container}

For the design of the chiral switchable container we intended to use the imidazole-containing peptides $\mathbf{2 a}\left(\mathrm{R}=\mathrm{R}^{\prime}=\mathrm{iPr}\right)$ and $\mathbf{3 a}$ $\left(\mathrm{R}=\mathrm{R}^{\prime}=\mathrm{iPr}\right)$ as macrocycles (see Figure 1 and Scheme 1 ). Both feature two imidazole units which should be used to attach the azobenzene groups. Additionally, platform 2a has two valine units, whereas platform 3a possesses two oxazole rings. Overall, both macrocycles feature four amino acid side chains (isopropyl groups), whereby all of them are of the same configuration $(S)$. Therefore, they are presented on one face of the macrocycle in a convergent manner.

Platform 3a was synthesized in a few steps according to a known procedure (Scheme 1) [51]. Therefore, the imidazole- 
a)

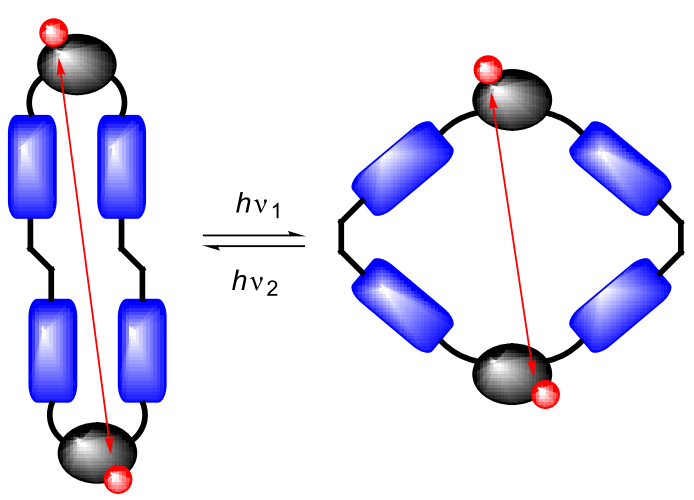

b)

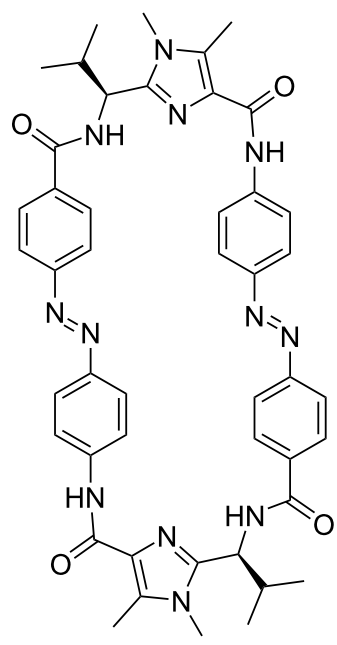

trans, trans-4

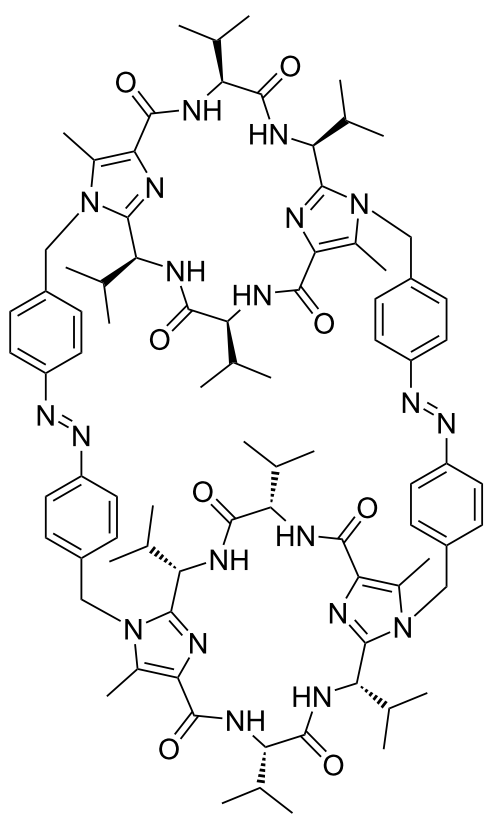

trans,trans-5

Figure 2: a) Principle of a chiral foldable platform and container based on Lissoclinum cyclopeptide alkaloids. b) Switchable molecular platform $\mathbf{4}$ and switchable molecular container 5 .

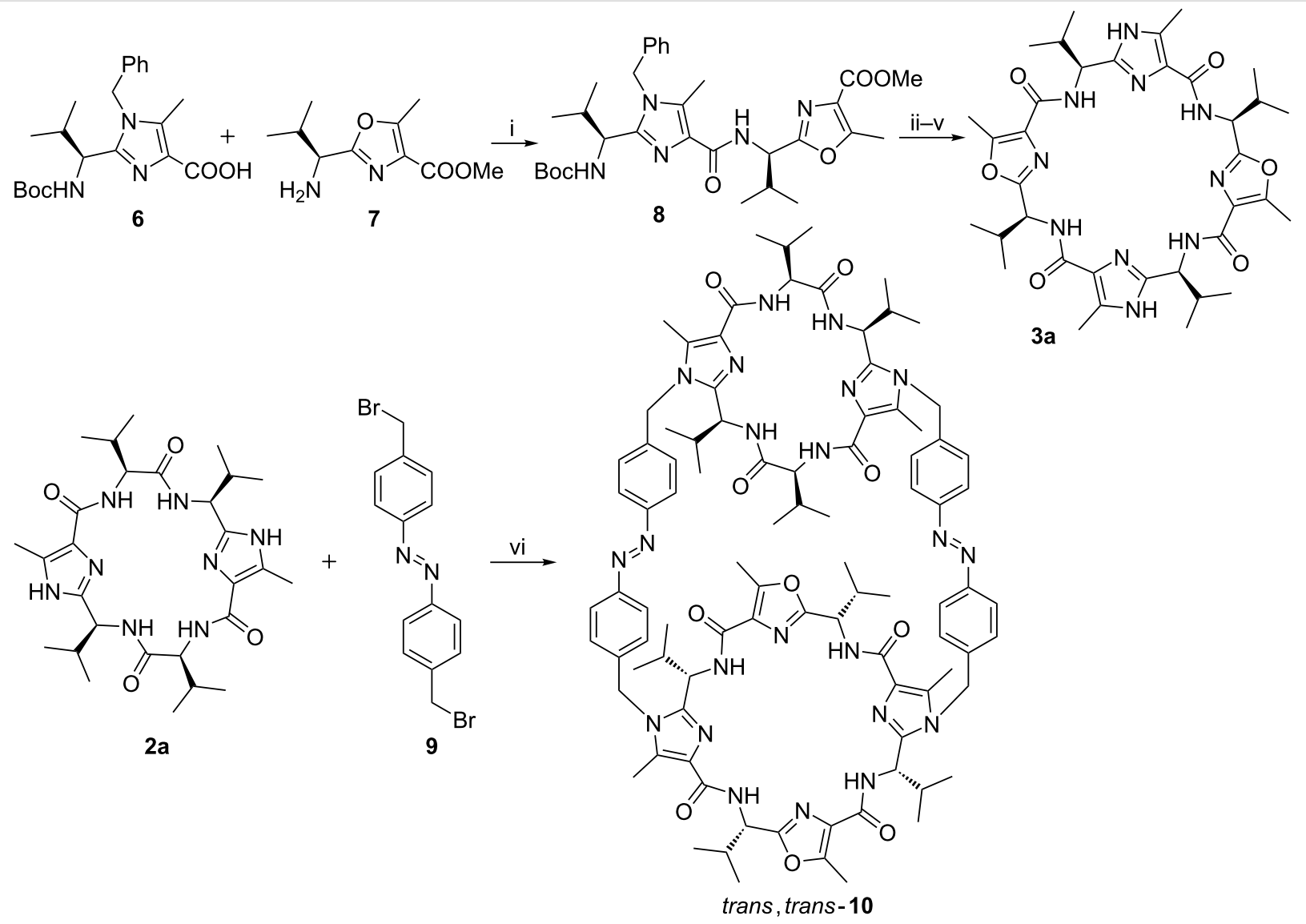

Scheme 1: Synthesis of the chiral foldable container 10. Reaction conditions: i) FDPP, iPr $\mathrm{PEEt}_{2} \mathrm{CH}_{3} \mathrm{CN}, 90 \%$; ii) $\mathrm{MeOH}$, dioxane, $\mathrm{NaOH}$, quant.; iii) EtOAc, $\mathrm{HCl}$, quant.; iv) FDPP, $\mathrm{iPr}_{2} \mathrm{NEt}, \mathrm{CH}_{3} \mathrm{CN}, 50 \%$; v) $\mathrm{MeOH}, \mathrm{Pd}(\mathrm{OH})_{2} / \mathrm{C}, \mathrm{H}_{2}, 95 \%$; vi) $3 a, \mathrm{~K}_{2} \mathrm{CO}_{3}, \mathrm{CH}_{3} \mathrm{CN}, \Delta, 15 \%$. 
containing acid 6 was reacted with the free amine 7 using pentafluorophenyl diphenylphosphinate (FDPP) as coupling reagent resulting in the formation of amide $\mathbf{8}$. After saponification of the methyl ester and removal of the Boc protective group, the resulting amino acid was cyclodimerized to the benzyl-protected macrocycle. The yield for the cyclization amounts to about $50 \%$. The last step was the removal of the benzyl group by hydrogenolysis to yield the desired macrocycle 3a. The cyclopeptide 2a [52] is commercially available.

Initially, we tried to synthesize the chiral foldable container $\mathbf{1 0}$ starting from the macrocycles $\mathbf{2 a}$ and $\mathbf{3 a}$ in a stepwise manner. That means, we intended to react in a first step one macrocycle with two azobenzene units having each one reactive and one protected group. In a second step we wanted to transform the protected groups at the azobenzene units into reactive groups. The latter should react in a third step with the other macrocycle. However, although we varied the reaction sequence regarding the used macrocycles, none of these reaction pathways led to the desired molecule. Therefore, we changed our strategy and we tried to synthesize the chiral foldable container $\mathbf{1 0}$ in a one pot reaction. For this purpose, the platforms $\mathbf{2 a}$ and $\mathbf{3 a}$ and the dibromide 9 were dissolved in acetonitrile in the ratio 1:1:2.2. To this solution potassium carbonate as base was added and the whole mixture was refluxed for one day. Fortunately, the desired container was formed in a yield of $15 \%$, which is astonishingly good considering the multiple reaction paths. As byproducts the containers consisting of each two identical macrocycles 2a and 3a, respectively, are formed. These containers could not be separated from each other. The isolation of the desired container was achieved by column chromatography followed by HPLC. It is noteworthy that the synthesis of this container showing two different Lissoclinum cyclopeptides only took a couple of steps starting from an imidazole and an oxazole building block, an azobenzene unit as well as commercially available compounds.

\section{Investigation of the structure and the switching process}

To investigate the structures of the foldable container $\mathbf{1 0}$ in the gas phase, the geometric parameters of the trans,trans-, cis,trans- and cis,cis-isomers were fully optimized by means of the DFT potentials B3LYP [53-55] and B3LYP-D3 [56,57]. The latter includes an additional dispersion correction and describes dispersion interactions more accurately for larger atomic distances. As basis set 6-31G* [58,59] was applied. In the case of the cis,trans- and cis,cis-isomers we tried to calculate all possible conformations [cis,trans- $(M)$, cis,trans- $(P)$, cis, cis$(M, M)$, cis,cis- $(M, P)$ and cis,cis- $(P, P)]$. However, it turned out that the $P$ conformers represent no minima on the potential energy surface. Furthermore, single point calculations by means of the density functionals B3LYP and B3LYP-D3 were performed by using the basis set def2-TZVP $[60,61]$. The thus obtained data are listed in Table 1. The calculated structures are shown in Figure 3 and Figures S1 and S2 in Supporting Information File 1. For comparison, the data for azobenzene were also calculated using the same level of theory and are listed in Table 1.

\begin{tabular}{|c|c|c|}
\hline compound & $\Delta E^{\mathrm{a}}$ & $\Delta E^{\mathrm{b}}$ \\
\hline trans,trans-10 & 0.0 & 0.0 \\
\hline cis,trans-10 & 20.0 & 8.3 \\
\hline$c i s, c i s-10$ & 34.0 & 10.2 \\
\hline trans-azobenzene & 0.0 & 0.0 \\
\hline cis-azobenzene & 15.1 & 12.6 \\
\hline
\end{tabular}

aB3LYP/def2-TZVP//B3LYP/6-31G*. ${ }^{\mathrm{b} B 3 L Y P-D 3 / d e f 2-T Z V P / / B 3 L Y P-}$ $\mathrm{D} 3 / 6-31 \mathrm{G}^{*}$

A comparison of the data for azobenzene and the chiral container 10 calculated by means of B3LYP/def2-TZVP shows that the trans $\rightarrow$ cis isomerization of trans,trans-10 is associated with an energy increase of $20 \mathrm{kcal} / \mathrm{mol}$ (Table 1). The energy difference between trans-azobenzene and cis-azobenzene calculated at the same level of theory amounts to only $15.1 \mathrm{kcal} / \mathrm{mol}$. That means that the trans $\rightarrow$ cis isomerization of trans,trans -10 is accompanied by an introduction of additional strain energy of about $5 \mathrm{kcal} / \mathrm{mol}$. For the transition from trans,trans $\mathbf{- 1 0}$ to cis,cis-10 an energy of $34.0 \mathrm{kcal} / \mathrm{mol}$ is required. This is ca. $4 \mathrm{kcal} / \mathrm{mol}$ more than twice the energy of the trans $\rightarrow$ cis isomerization of azobenzene. Accordingly, the cis,cis-10 exhibits an additional strain energy of about $4 \mathrm{kcal} / \mathrm{mol}$ compared to trans, trans $\mathbf{- 1 0}$.

A completely different picture emerges when the dispersion correction D3 is taken into account (B3LYP-D3/def2-TZVP; Table 1). The trans $\rightarrow$ cis isomerization of trans, trans $\mathbf{- 1 0}$ to cis,trans-10 is energetically favored $(8.3 \mathrm{kcal} / \mathrm{mol})$ compared to the transition from trans-azobenzene to cis-azobenzene $(12.6 \mathrm{kcal} / \mathrm{mol})$. The energy input for the switching process between cis,trans $\mathbf{- 1 0}$ to cis,cis $\mathbf{- 1 0}$ amounts to only $1.9 \mathrm{kcal} / \mathrm{mol}$. The reason for that is the high gain of attractive dispersion interactions due to the compact structure of the cis,cis-isomer. Therefore, we expected that the switching process from cis,trans $\mathbf{- 1 0}$ to cis,cis-10 is more easily realizable by an extern light stimulus than the transition from trans,trans-10 to cis,trans-10. This would be very much in line with our idea to design an chiral container which can be switched between two main states (trans,trans and cis,cis). 


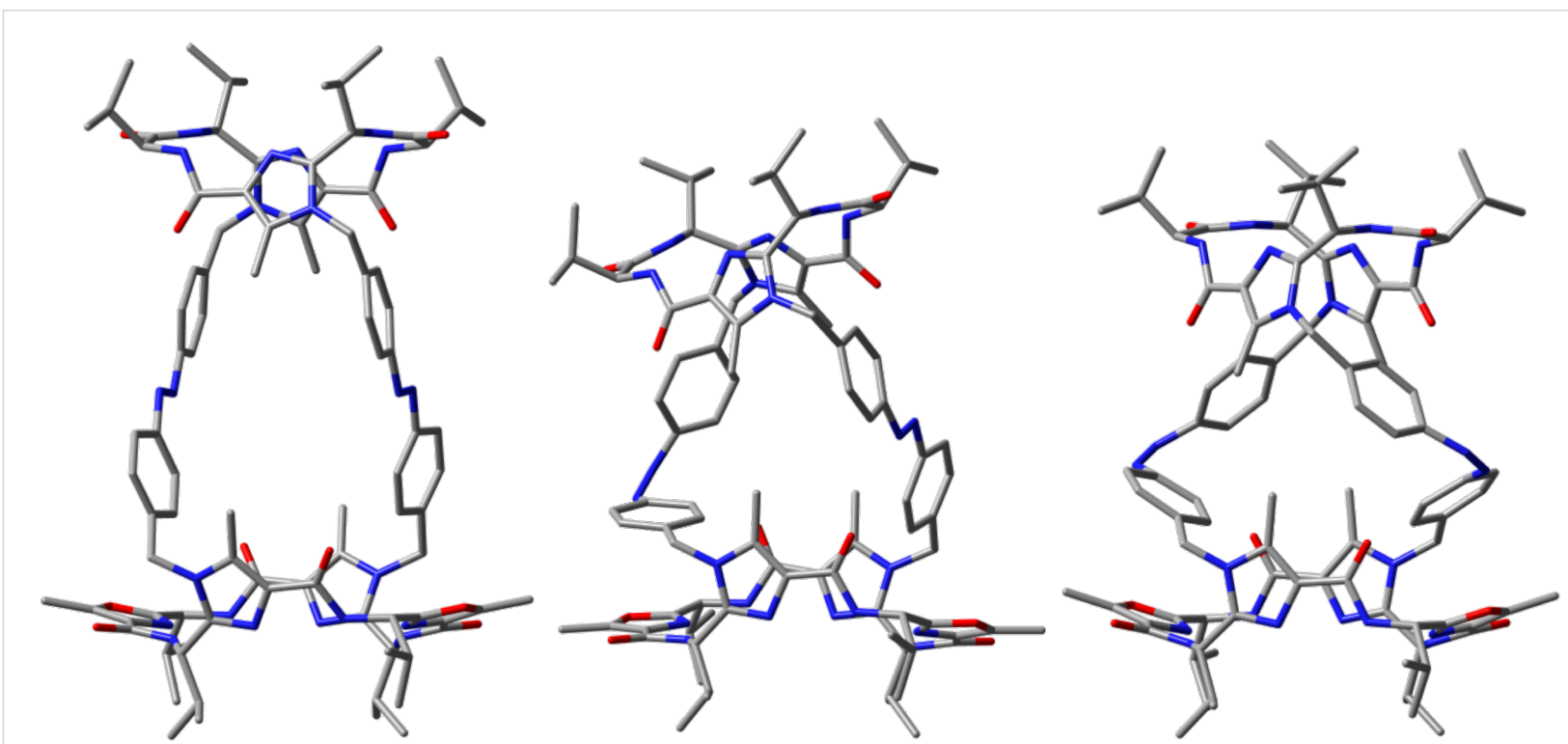

Figure 3: Molecular structures of trans,trans-10 (left), cis,trans-10 (middle) and cis,cis-10 (right) calculated by means of B3LYP/6-31G*. All hydrogen atoms are omitted for the sake of clarity.

The structures of the three isomers of container $\mathbf{1 0}$ calculated by means of B3LYP/6-31G* are depicted in Figure 3. As expected, the connection of the two macrocycles $\mathbf{2 a}$ and $\mathbf{3 a}$ via two transazobenzenes (trans,trans-10) results in a longer distance between the macrocycles compared to a connection via two cisazobenzenes (cis,cis-10). The distance between the centers of the two macrocycles in the trans,trans-isomer amounts to 14.1 $\AA$. For cis,cis-10 a decrease of this distance to $11.3 \AA$ is calculated. The corresponding value for the cis,trans isomer amounts to $11.8 \AA$, which is only slightly larger compared to the data of cis,cis-10. Therefore, according to the calculations the chiral container $\mathbf{1 0}$ should show the desired change caused by extern stimulation.

It is notable that the switching process from trans,trans-10 to cis,cis-10 is accompanied by a clockwise rotation of the two macrocycles towards each other. This could be explained as follows: In trans,trans-10 the two azobenzene bridges are not perpendicularly arranged to the macrocycles, but they show a left-hand twist (Figure 3 and Figure S1 in Supporting Information File 1). The trans $\rightarrow$ cis isomerization enhances this lefthand twist leading to a clockwise rotation of the two macrocycles towards each other.

To prove the switching process experimentally, the UV spectra of the container $\mathbf{1 0}$ in acetonitrile as solvent were recorded (Figure 4). After the synthesis, the UV spectrum of the container shows an intensive band at $323 \mathrm{~nm}$ and a weak band at ca. $450 \mathrm{~nm}$. The absorption at $323 \mathrm{~nm}$ corresponds to the $\pi \rightarrow \pi^{*}$ transition, the second one is caused by the $n \rightarrow \pi^{*}$ transi- tion. Irradiation of the solution with UV light of the length $\lambda=365 \mathrm{~nm}$ leads to a strong decrease of the absorption band at $323 \mathrm{~nm}$ and to a hypsochromic shift of the $n \rightarrow \pi^{*}$ transition band to ca. $430 \mathrm{~nm}$ (Figure 4). These changes are typical for the transition of trans-azobenzene units to the corresponding cisisomers. A back-isomerization could be achieved by irradiation of the solution with light of the wavelength $\lambda=405 \mathrm{~nm}$. The switching process could be repeated several times without a significant change of the spectra.

In order to determine the ratio of the three isomers of the container $\mathbf{1 0}$ in dependence on the used light, the whole process was investigated by using HPLC and NMR spectroscopy. In both cases methanol was used as solvent. The switching processes caused by light were carried out with LED lamps and the solution was irradiated until the photostationary states were reached. In Figure 5 the ${ }^{1} \mathrm{H}$ NMR spectra of the container $\mathbf{1 0}$ are depicted. After the synthesis, the foldable container is predominantly present as trans,trans-isomer (Figure 5a). The other signals in the spectrum stem from the $C_{1}$-symmetric cis,transisomer, which can easily be recognized by the large number of signals. The ratio trans,trans/cis,trans/cis, cis was determined to be $68: 31:<1$.

Irradiation with light of the wavelength $\lambda=365 \mathrm{~nm}$ results in the formation of the cis,trans- and cis,cis-isomers. Accordingly, a trans,trans/cis,trans/cis, cis ratio of 12:39:49 can be found (Figure 5b). If this mixture is now irradiated with light of the wavelength $\lambda=405 \mathrm{~nm}$ the trans,trans-isomer is formed back and the trans,trans/cis,trans/cis,cis ratio changes to $77: 22:<1$ 


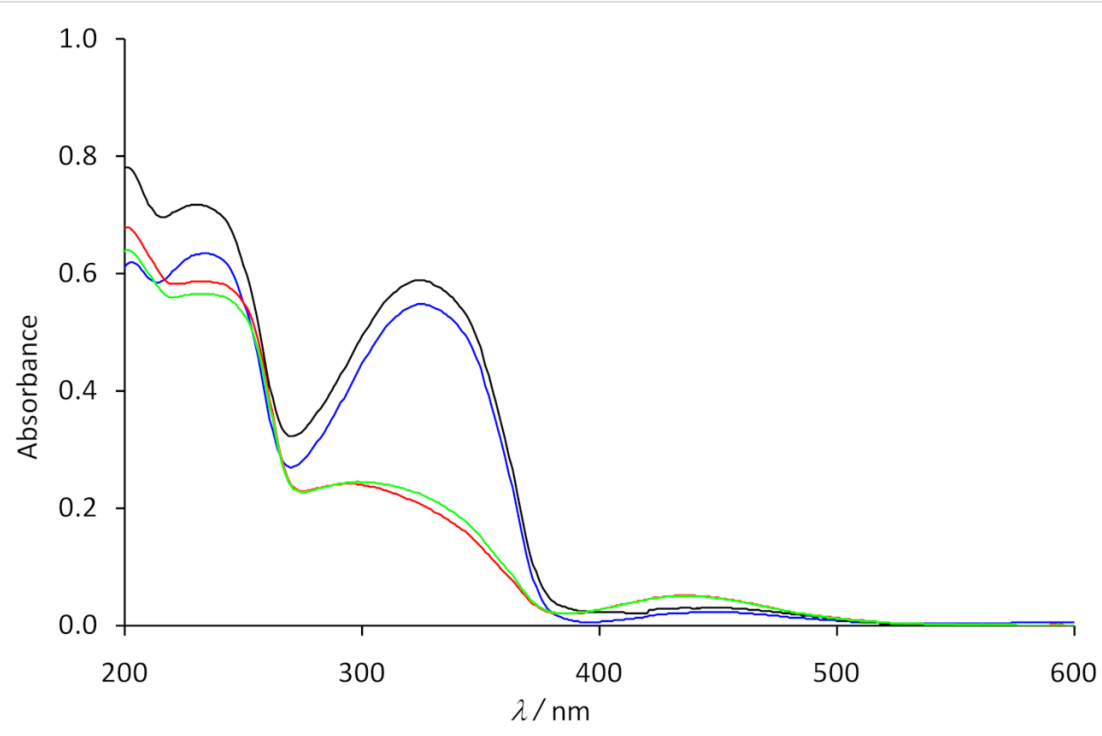

Figure 4: UV spectra of the foldable container 10 in acetonitrile after synthesis (blue), after irradiation with light of the wavelength $\lambda=365 \mathrm{~nm}$ (red), after irradiation with light of the wavelength $\lambda=405 \mathrm{~nm}$ (black) and after irradiation with light of the wavelength $\lambda=365 \mathrm{~nm}$ (green).

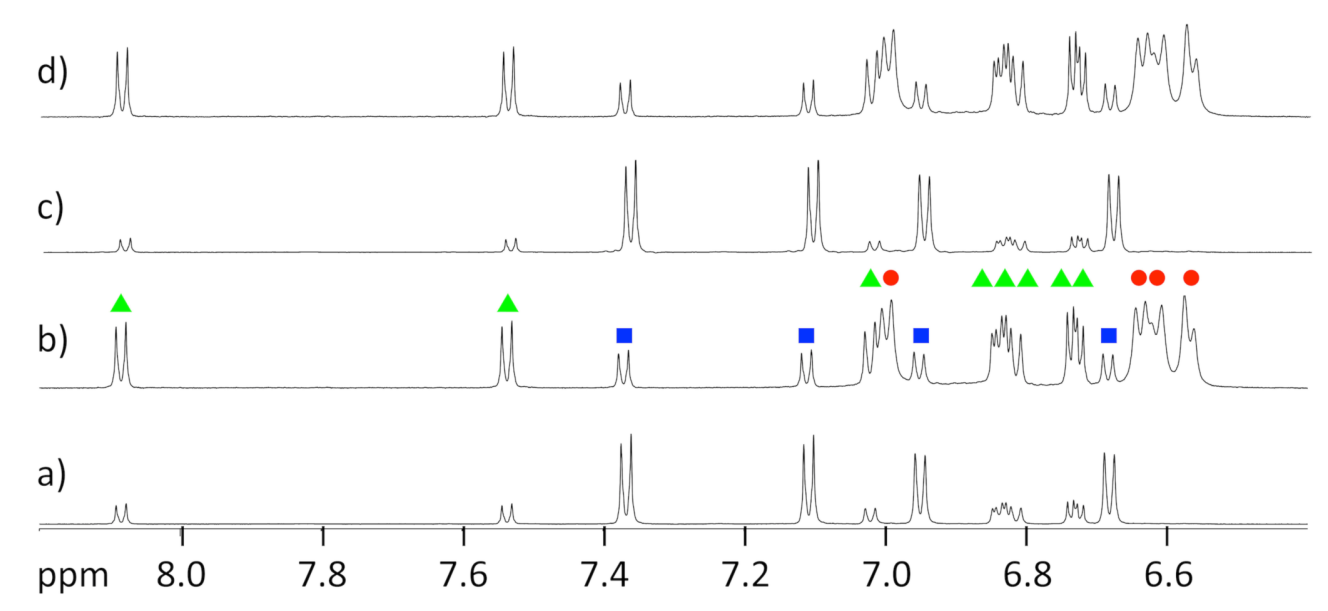

Figure 5: Section from the ${ }^{1} \mathrm{H}$ NMR spectra of the foldable container 10 in MeOD at $600 \mathrm{MHz}$ : a) after synthesis, b) after irradiation with light of the wavelength $\lambda=365 \mathrm{~nm}, \mathrm{c}$ ) after irradiation with light of the wavelength $\lambda=405 \mathrm{~nm}$ and d) after irradiation with light of the wavelength $\lambda=365 \mathrm{~nm}$. The protons of the isomers trans,trans-10 (blue squares), cis,trans-10 (green triangles) and cis,cis-10 (red circles) are marked.

(Figure 5c). The switching process can be repeated without a significant change of the spectrum (Figure $5 \mathrm{~d}$; trans,trans/ cis, trans/cis,cis ratio $=11: 39: 50)$.

The HPLC spectra of the investigation of the switching process are shown in the Supporting Information File 1 (Figures S3-S6). A comparison of the corresponding ${ }^{1} \mathrm{H}$ NMR spectra shows that the extent of the switching process is dependent on the concentration of the azo compound. The more diluted the solution, the larger are the changes caused by the LED lamps. This effect is already known for this kind of switches [49,50]. The trans,trans/cis,trans/cis, cis ratio of the solution after synthesis amounts to $63: 35: 2$ and resemble the ${ }^{1} \mathrm{H}$ NMR data
$(68: 31:<1)$. After irradiation with light of the wavelength $\lambda=365 \mathrm{~nm}$ a trans,trans/cis,trans/cis, cis ratio of $4: 26: 70$ is observed, which is distinctly higher than that found using ${ }^{1} \mathrm{H}$ NMR spectroscopy (12:39:49). Also the back-isomerization caused by light of the wavelength $\lambda=405 \mathrm{~nm}$ results in an higher amount of the trans,trans-isomer (trans,trans/cis,trans/ cis,cis $=80: 19: 1)$. It is also possible to get a mixture having the cis,trans-isomer as main component, if the solution is exposed to light of the wavelength $\lambda=530 \mathrm{~nm}$ (trans,trans/cis,trans/ cis, cis $=8: 60: 32$ ).

The use of preparative HPLC allows the isolation of the single isomers and the investigation of the separated compounds. 
Therefore, the single HPLC peaks were collected and measured within a few minutes by CD spectroscopy. The purity of the separated isomers was tested as follows: after collection of the single HPLC peaks and a waiting time of about $20 \mathrm{~min}$, HPLC chromatograms of the single fractions were recorded. These chromatograms show a purity of $>93 \%$ for each isomer (Figure 6).

The CD spectra of the single isomers of the container $\mathbf{1 0}$ are shown in Figure 7. It should be mentioned that the area around $450 \mathrm{~nm}$ of the CD spectra of simple alkyl-substituted cis- azobenzene derivatives is dominated by only one transition $\left(\mathrm{n} \rightarrow \pi^{*}\right)$. Accordingly, the conformation $(M$ or $P)$ of the cisazobenzene moiety can directly be identified from the sign of the Cotton effect at $450 \mathrm{~nm}$. Previous studies have demonstrated that the cis- $(M)$ isomer shows a positive and the cis- $(P)$ isomer has a negative Cotton effect in this region [43,49]. If this is taken into account, it becomes obvious that the cis,cis-isomer adopts the $M, M$ conformation. This is in line with the DFT calculations finding only the $\operatorname{cis}$, cis- $(M, M)$ isomer as minimum on the energy potential surface. The spectrum of cis,trans-10 allows the conclusion that the cis-azobenzene unit is present in

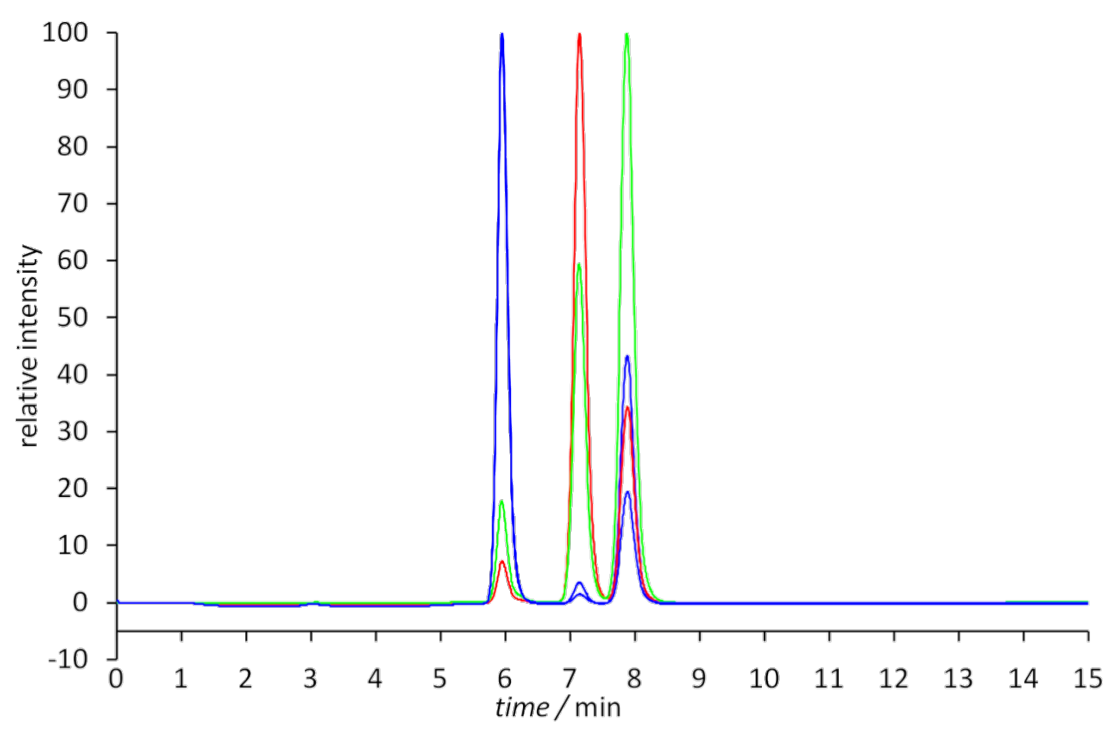

Figure 6: HPLC spectra (ReproSil Phenyl, $5 \mu \mathrm{m}, 250 \times 8 \mathrm{~mm}$; methanol) of trans,trans-10 (blue), cis,trans-10 (green) and cis,cis-10 (red) 20 min after isolation by means of HPLC.

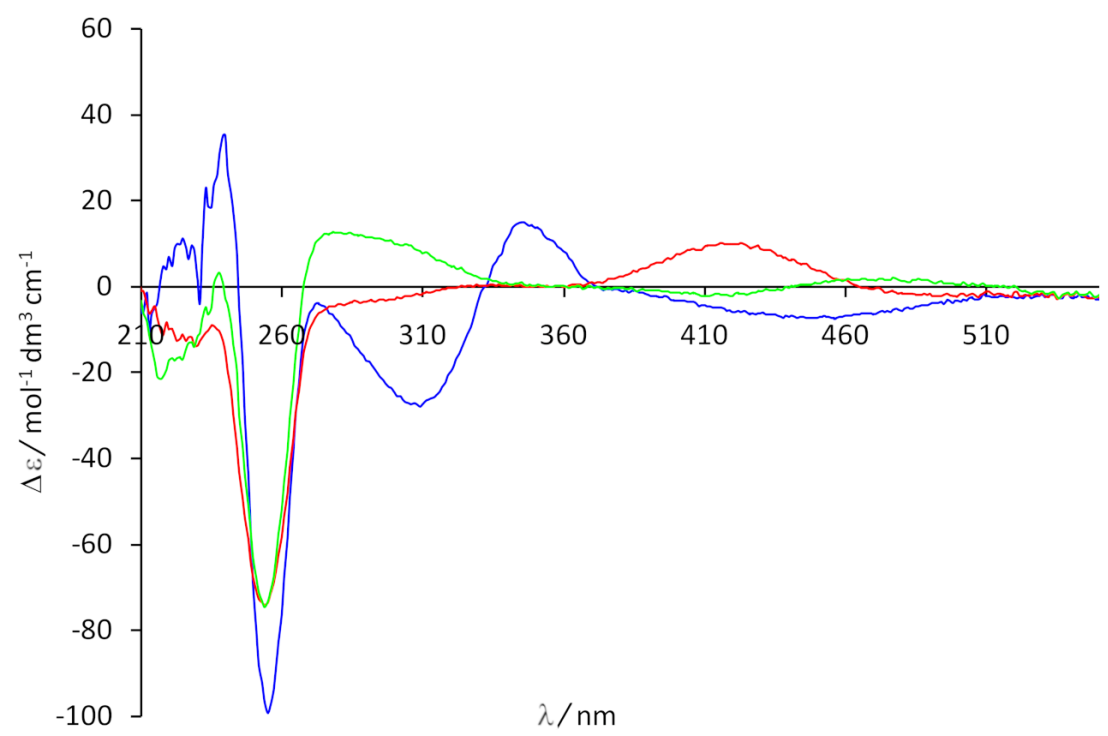

Figure 7: CD spectra of trans,trans-10 (blue), cis,trans-10 (green), and cis, cis-10 (red) in methanol $\left(c=3.0 \times 10^{-5} \mathrm{M}\right)$. 
its $M$ conformation. For the $P$ conformation we would expect a negative Cotton in the area around $450 \mathrm{~nm}$. That means the chiral information is transferred from both macrocycles to the cis-azobenzene units in cis,trans-(M)-10 and cis,cis-(M,M)-10 and the two different macrocycles perform a definite clockwise rotation to the other caused by irradiation with UV light and a counterclockwise rotation when the compound is exposed to visible light.

The spatial change of the container $\mathbf{1 0}$ caused by the switching process could have an impact on the size of the diffusion coefficient of the compound. To examine this, DOSY spectra of the container $\mathbf{1 0}$ after synthesis and after irradiation with light of the wavelength $\lambda=365 \mathrm{~nm}$ were recorded (Figure 8). Please note, that a change in the geometry of a switch need not result in a change of the size of the diffusion coefficient. For example, neither for the switchable platform $\mathbf{5}$ nor for the foldable container $\mathbf{6}$ a significant change of the diffusion coefficients caused by the switching process could be detected in the DOSY spectra of the compounds. This can be explained as follows: The DOSY NMR experiment measures the average dimension of the structures of the isomers which, summed up over all directions, could be very comparable. However, a comparison of the DOSY spectra of trans,trans-10 and cis,cis-10 shows that the diffusion coefficient of the elongated trans,trans $\mathbf{- 1 0}$ is indeed larger than that of the more compact cis,cis-isomer (Figure 8).

\section{Conclusion}

In conclusion, we were able to synthesize a foldable container consisting of two different types of Lissoclinum macrocyclic peptides which are connected via two azobenzene units. The synthesis of this container was achieved by a one pot reaction of the two imidazole-containing macrocycles and the azobenzene bridges having two reactive bromides. The desired container could be isolated in a fair yield taking the multiple reaction pathways into account. Subsequent investigations by means of quantum chemical calculations, UV, CD and NMR spectroscopy revealed that the container can be switched using UV light from the trans,trans-isomer into the cis,cis-isomer. Irradiation with visible light results in the back-isomerization. The switching process is spatially directed, accompanied by a change in the diffusion coefficient and in the distance between the centers of the two macrocycles: In the elongated trans,trans-isomer this distance shows a value of $14.1 \AA$, in the more compact cis,cis-isomer the distance amounts to $11.3 \AA$. The replace of the isopropyl groups by recognition units and the enlargement of the two linkers, which makes a shielding of a guest from the environment possible, should lead to containers which are due to their foldable feature promising candidates for applications in supramolecular chemistry.

\section{Experimental}

General remarks: All chemicals were reagent grade and were used as purchased. Reactions were monitored by TLC analysis with silica gel 60 F254 thin-layer plates. Flash chromatography was carried out on silica gel 60 (230-400 mesh). ${ }^{1} \mathrm{H}$ and ${ }^{13} \mathrm{C}$ NMR spectra were measured with an Avance HD 600 spectrometer. All chemical shifts ( $\delta$ ) are given in ppm. The spectra were referenced to the peak for the protium impurity in the deuterated solvents indicated in brackets in the analytical data. HRMS spectra were recorded with a Bruker BioTOF III Instru-

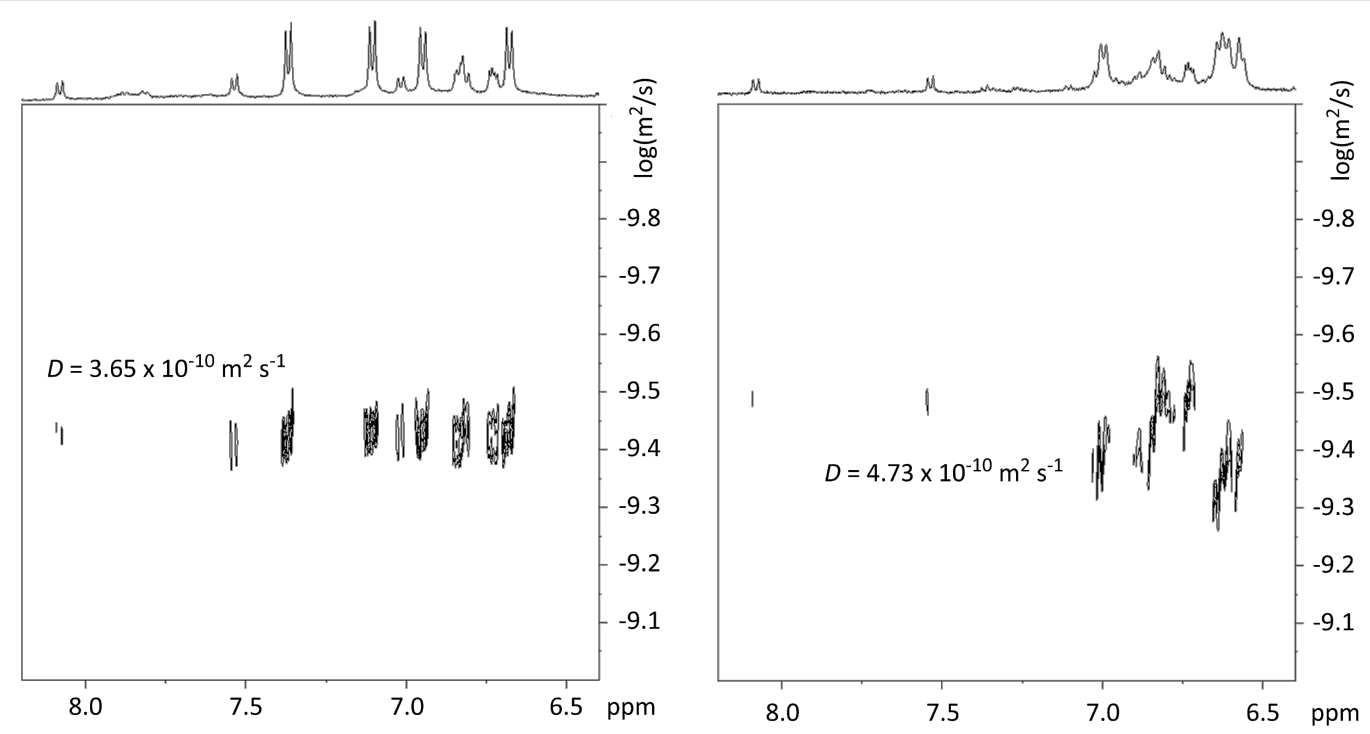

Figure 8: DOSY NMR spectra $\left(500 \mathrm{MHz}\right.$ in MeOD at $\left.25^{\circ} \mathrm{C}\right)$ of the foldable container 10 after synthesis (left) and after irradiation with light of the wavelength $\lambda=365 \mathrm{~nm}$ (right). 
ment. UV-vis absorption spectra were obtained with Jasco J-815 and V-550 spectrophotometers. CD absorption spectra were recorded with a Jasco J-815 spectrophotometer. The IR absorption spectrum was recorded with a Varian 3100 FTIR spectrophotometer. The macrocycle 3a was synthesized according to a known procedure [51]. The macrocycle 2a was purchased from Squarix $\mathrm{GmbH}$.

Chiral container trans,trans-10: To a solution of macrocycle 3a (128 mg, $0.178 \mathrm{mmol}$ ), macrocycle $2 \mathbf{a}$ ( $99 \mathrm{mg}, 0.178 \mathrm{mmol}$ ), and azobenzene $9(144 \mathrm{mg}, 0.391 \mathrm{mmol})$ in acetonitrile $(225 \mathrm{~mL})$, potassium carbonate $(491 \mathrm{mg}, 3.554 \mathrm{mmol})$ was added and the mixture was refluxed at $85^{\circ} \mathrm{C}$ for $25 \mathrm{~h}$ under an argon atmosphere. After cooling to room temperature, the solvent was evaporated to dryness, the residue was dissolved in DCM and washed with water. The aqueous layer was saturated with $\mathrm{NaCl}$ and then repeatedly extracted with DCM. The organic layers were combined, dried over $\mathrm{MgSO}_{4}$ and concentrated in vacuo. Afterwards, the residue was purified by flash column chromatography with silica gel (DCM/EtOAc/MeOH 75:25:5) and trans,trans-10 was obtained as an orange solid (47 mg, $28 \mu \mathrm{mol}, 15 \%)$. Mp >250 ${ }^{\circ} \mathrm{C}$; ${ }^{1} \mathrm{H}$ NMR $(600 \mathrm{MHz}$, MeOD) $\delta 7.38\left(\mathrm{~d},{ }^{3} J_{\mathrm{H}, \mathrm{H}}=8.4 \mathrm{~Hz}, 4 \mathrm{H}, \mathrm{C}_{\mathrm{ar}} \mathrm{H}\right), 7.12\left(\mathrm{~d},{ }^{3} J_{\mathrm{H}, \mathrm{H}}=\right.$ $\left.8.4 \mathrm{~Hz}, 4 \mathrm{H}, \mathrm{C}_{\mathrm{ar}} \mathrm{H}\right), 6.96\left(\mathrm{~d},{ }^{3} J_{\mathrm{H}, \mathrm{H}}=8.4 \mathrm{~Hz}, 4 \mathrm{H}, \mathrm{C}_{\mathrm{ar}} \mathrm{H}\right), 6.69(\mathrm{~d}$, $\left.{ }^{3} J_{\mathrm{H}, \mathrm{H}}=8.4 \mathrm{~Hz}, 4 \mathrm{H}, \mathrm{C}_{\mathrm{ar}} \mathrm{H}\right), 5.72\left(\mathrm{~d},{ }^{2} J_{\mathrm{H}, \mathrm{H}}=16.9 \mathrm{~Hz}, 2 \mathrm{H}\right.$, $\left.\mathrm{CH}_{2} \mathrm{C}_{\mathrm{ar}}\right), 5.51\left(\mathrm{~d},{ }^{2} J_{\mathrm{H}, \mathrm{H}}=16.6 \mathrm{~Hz}, 2 \mathrm{H}, \mathrm{CH}_{2} \mathrm{C}_{\mathrm{ar}}\right), 5.24(\mathrm{~d}$, $\left.{ }^{3} J_{\mathrm{H}, \mathrm{H}}=9.3 \mathrm{~Hz}, 2 \mathrm{H}, \mathrm{NHCH}\right), 5.21\left(\mathrm{~d},{ }^{2} J_{\mathrm{H}, \mathrm{H}}=16.9 \mathrm{~Hz}, 2 \mathrm{H}\right.$, $\left.\mathrm{CH}_{2} \mathrm{C}_{\mathrm{ar}}\right), 5.06\left(\mathrm{~d},{ }^{2} J_{\mathrm{H}, \mathrm{H}}=16.6 \mathrm{~Hz}, 2 \mathrm{H}, \mathrm{CH}_{2} \mathrm{C}_{\mathrm{ar}}\right), 5.03(\mathrm{~d}$, $\left.{ }^{3} J_{\mathrm{H}, \mathrm{H}}=8.0 \mathrm{~Hz}, 2 \mathrm{H}, \mathrm{NHCH}\right), 4.81\left(\mathrm{~d},{ }^{3} J_{\mathrm{H}, \mathrm{H}}=8.7 \mathrm{~Hz}, 2 \mathrm{H}\right.$, $\mathrm{NHCH}), 4.25\left(\mathrm{~d},{ }^{3} J_{\mathrm{H}, \mathrm{H}}=9.6 \mathrm{~Hz}, 2 \mathrm{H}, \mathrm{NHCH}\right), 2.61-2.53(\mathrm{~m}$, $\left.2 \mathrm{H}, \mathrm{CH}\left(\mathrm{CH}_{3}\right)_{2}\right), 2.48\left(\mathrm{~s}, 6 \mathrm{H}, \mathrm{C}_{\mathrm{azol}} \mathrm{CH}_{3}\right), 2.44-2.35(\mathrm{~m}, 4 \mathrm{H}$, $\left.\mathrm{CH}\left(\mathrm{CH}_{3}\right)_{2}\right), 2.28\left(\mathrm{~s}, 6 \mathrm{H}, \mathrm{C}_{\mathrm{azol}} \mathrm{CH}_{3}\right), 2.27\left(\mathrm{~s}, 6 \mathrm{H}, \mathrm{C}_{\mathrm{azol}} \mathrm{CH}_{3}\right)$, 2.24-2.19 (m, 2H, CH(CH$\left.)_{2}\right), 1.20\left(\mathrm{~d},{ }^{3} \mathrm{~J}_{\mathrm{H}, \mathrm{H}}=6.7 \mathrm{~Hz}, 6 \mathrm{H}\right.$, $\left.\mathrm{CH}\left(\mathrm{CH}_{3}\right)_{2}\right), 1.16\left(\mathrm{~d},{ }^{3} \mathrm{~J}_{\mathrm{H}, \mathrm{H}}=6.5 \mathrm{~Hz}, 6 \mathrm{H}, \mathrm{CH}\left(\mathrm{CH}_{3}\right)_{2}\right), 1.15(\mathrm{~d}$, $\left.{ }^{3} J_{\mathrm{H}, \mathrm{H}}=6.5 \mathrm{~Hz}, 6 \mathrm{H}, \mathrm{CH}\left(\mathrm{CH}_{3}\right)_{2}\right), 1.10\left(\mathrm{~d},{ }^{3} J_{\mathrm{H}, \mathrm{H}}=6.8 \mathrm{~Hz}, 6 \mathrm{H}\right.$, $\left.\mathrm{CH}\left(\mathrm{CH}_{3}\right)_{2}\right), 1.09\left(\mathrm{~d},{ }^{3} \mathrm{~J}_{\mathrm{H}, \mathrm{H}}=6.7 \mathrm{~Hz}, 6 \mathrm{H}, \mathrm{CH}\left(\mathrm{CH}_{3}\right)_{2}\right), 1.01(\mathrm{~d}$, $\left.{ }^{3} J_{\mathrm{H}, \mathrm{H}}=6.7 \mathrm{~Hz}, 6 \mathrm{H}, \mathrm{CH}\left(\mathrm{CH}_{3}\right)_{2}\right), 0.98\left(\mathrm{~d},{ }^{3} J_{\mathrm{H}, \mathrm{H}}=6.7 \mathrm{~Hz}, 6 \mathrm{H}\right.$, $\left.\mathrm{CH}\left(\mathrm{CH}_{3}\right)_{2}\right), 0.93\left(\mathrm{~d},{ }^{3} \mathrm{~J}_{\mathrm{H}, \mathrm{H}}=6.8 \mathrm{~Hz}, 6 \mathrm{H}, \mathrm{CH}\left(\mathrm{CH}_{3}\right)_{2}\right) \mathrm{ppm}$; ${ }^{13} \mathrm{C}$ NMR (151 MHz, MeOD) $\delta 174.0$ (q, CO), 165.8 (q, CO), 165.3 (q, CO), 164.5 (q, CO), 162.9 (q, C $\mathrm{Cr}_{\mathrm{ar}}$ ), 154.9 (q, $\mathrm{C}_{\mathrm{ar}}$ ), $152.8\left(\mathrm{q}, \mathrm{C}_{\mathrm{ar}}\right), 152.2\left(\mathrm{q}, \mathrm{C}_{\mathrm{ar}}\right), 148.6\left(\mathrm{q}, \mathrm{C}_{\mathrm{ar}}\right), 148.1\left(\mathrm{q}, \mathrm{C}_{\mathrm{ar}}\right)$, $140.8\left(\mathrm{q}, \mathrm{C}_{\mathrm{ar}}\right), 140.6\left(\mathrm{q}, \mathrm{C}_{\mathrm{ar}}\right), 135.5\left(\mathrm{q}, \mathrm{C}_{\mathrm{ar}}\right), 135.1$ (q, $\left.\mathrm{C}_{\mathrm{ar}}\right)$, 131.4 (q, $\mathrm{C}_{\mathrm{ar}}$ ), 131.0 (q, $\mathrm{C}_{\mathrm{ar}}$ ), 129.7 (q, $\mathrm{C}_{\mathrm{ar}}$ ), 128.3 (t, $\mathrm{C}_{\mathrm{ar}}$ ), $128.1\left(\mathrm{t}, \mathrm{C}_{\mathrm{ar}}\right), 124.5\left(\mathrm{t}, \mathrm{C}_{\mathrm{ar}}\right), 124.2\left(\mathrm{t}, \mathrm{C}_{\mathrm{ar}}\right), 62.4(\mathrm{t}, \mathrm{CHNH}), 54.6$ (t, $\mathrm{CHNH}), 52.4(\mathrm{t}, \mathrm{CHNH}), 51.0(\mathrm{t}, \mathrm{CHNH}), 48.2\left(\mathrm{~s}, \mathrm{CH}_{2} \mathrm{C}_{\mathrm{ar}}\right)$, 48.1 (s, $\mathrm{CH}_{2} \mathrm{C}_{\mathrm{ar}}$ ), 35.9 (t, $\left.\mathrm{CH}\left(\mathrm{CH}_{3}\right)_{2}\right), 34.7$ (t, $\left.\mathrm{CH}\left(\mathrm{CH}_{3}\right)_{2}\right), 33.1$ (t, $\left.\mathrm{CH}\left(\mathrm{CH}_{3}\right)_{2}\right), 31.5$ (t, $\left.\mathrm{CH}\left(\mathrm{CH}_{3}\right)_{2}\right), 20.3\left(\mathrm{p}, \mathrm{CH}\left(\mathrm{CH}_{3}\right)_{2}\right), 20.0$ (p, $\left.\mathrm{CH}\left(\mathrm{CH}_{3}\right)_{2}\right), 19.8$ (p, $\left.\mathrm{CH}\left(\mathrm{CH}_{3}\right)_{2}\right), 19.7$ (p, $\left.\mathrm{CH}\left(\mathrm{CH}_{3}\right)_{2}\right), 19.6$ (p, $\left.\mathrm{CH}\left(\mathrm{CH}_{3}\right)_{2}\right), 19.5$ (p, $\left.\mathrm{CH}\left(\mathrm{CH}_{3}\right)_{2}\right), 19.5$ (p, $\left.\mathrm{CH}\left(\mathrm{CH}_{3}\right)_{2}\right), 19.2$ (p, $\left.\mathrm{CH}\left(\mathrm{CH}_{3}\right)_{2}\right), 11.6\left(\mathrm{p}, \mathrm{C}_{\mathrm{q}} \mathrm{CH}_{3}\right), 10.9\left(\mathrm{p}, \mathrm{C}_{\mathrm{q}} \mathrm{CH}_{3}\right), 10.6$ (p, $\mathrm{C}_{\mathrm{q}} \mathrm{CH}_{3}$ ) ppm; IR (ATR) v: 3398, 2963, 2929, 2873, 1661, 1653,
1592, 1506, 1498, 1458, 1188, 1110, 761, $715 \mathrm{~cm}^{-1}$; UV-vis $\left(\mathrm{CH}_{3} \mathrm{CN}\right) \lambda_{\max }(\log \varepsilon): 202$ (4.69), 229 (4.69), 328 (4.50), $445 \mathrm{~nm}$ (2.99); HRMS (ESI-TOF) $\mathrm{m} / \mathrm{z}:[\mathrm{M}+\mathrm{H}]^{+}$calcd for $\mathrm{C}_{92} \mathrm{H}_{115} \mathrm{~N}_{22} \mathrm{O}_{10}, 1687.9161$; found, 1687.9103; [M $\left.+\mathrm{Na}\right]^{+}$ calcd for $\mathrm{C}_{92} \mathrm{H}_{114} \mathrm{~N}_{22} \mathrm{O}_{10} \mathrm{Na}$, 1709.8980; found, 1709.8929 .

Calculations. All calculations were performed by using the program package Gaussian 16 [62]. The geometries of the molecules were fully optimized in the gas phase by using the DFT potentials B3LYP [53-55] and B3LYP-D3 [56,57] as well as the $6-31 G^{*}[58,59]$ basis set. For all calculations, the default thresholds implemented in Gaussian 16 were used. For all stationary points, no symmetry restriction was applied. The optimized geometries of all structures were characterized as minima by subsequent frequency calculations. Furthermore, the energies of the molecules were calculated using the DFT potentials B3LYP [53-55] and B3LYP-D3 [56,57] as well as the def2TZVP [60,61] basis set.

\section{Supporting Information}

\section{Supporting Information File 1}

Molecular structures, HPLC spectra of the foldable container, cartesian coordinates and absolute energies for all calculated compounds, as well as the NMR spectra of the new chiral container.

[https://www.beilstein-journals.org/bjoc/content/ supplementary/1860-5397-15-156-S1.pdf]

\section{Acknowledgements}

This work was generously supported by the Professor Werdelmann-Stiftung (T167/23664/2013).

\section{ORCID ${ }^{\circledR}$ iDs}

Abdulselam Adam - https://orcid.org/0000-0003-3588-5737

Gebhard Haberhauer - https://orcid.org/0000-0002-5427-7510

\section{Preprint}

A non-peer-reviewed version of this article has been previously published as a preprint doi:10.3762/bxiv.2019.9.v1

\section{References}

1. Steed, J. W.; Atwood, J. L. Supramolecular Chemistry, 2nd ed.; John Wiley \& Sons: Chichester, UK, 2009. doi:10.1002/9780470740880

2. Michael, J. P.; Pattenden, G. Angew. Chem., Int. Ed. Engl. 1993, 32, 1-23. doi:10.1002/anie.199300013

3. Jolliffe, K. A. Supramol. Chem. 2005, 17, 81-86. doi:10.1080/10610270412331328970

4. Young, P. G.; Clegg, J. K.; Bhadbhade, M.; Jolliffe, K. A. Chem. Commun. 2011, 47, 463-465. doi:10.1039/c0cc02223c 
5. Young, P. G.; Jolliffe, K. A. Org. Biomol. Chem. 2012, 10, 2664-2672. doi:10.1039/c2ob06964d

6. Dungan, V. J.; Ngo, H. T.; Young, P. G.; Jolliffe, K. A. Chem. Commun. 2013, 49, 264-266. doi:10.1039/c2cc37686e

7. Butler, S. J.; Jolliffe, K. A. Org. Biomol. Chem. 2011, 9, 3471-3483. doi:10.1039/c0ob01072c

8. Liu, X.; Ngo, H. T.; Ge, Z.; Butler, S. J.; Jolliffe, K. A. Chem. Sci. 2013, 4, 1680-1686. doi:10.1039/c3sc22233k

9. Haberhauer, G.; Oeser, T.; Rominger, F. Chem. - Eur. J. 2005, 11, 6718-6726. doi:10.1002/chem.200500224

10. Schnopp, M.; Haberhauer, G. Eur. J. Org. Chem. 2009, 4458-4467. doi:10.1002/ejoc.200900510

11. Bartfai, T.; Lu, X.; Badie-Mahdavi, H.; Barr, A. M.; Mazarati, A.; Hua, X.-Y.; Yaksh, T.; Haberhauer, G.; Ceide, S. C.; Trembleau, L.; Somogyi, L.; Kröck, L.; Rebek, J., Jr. Proc. Natl. Acad. Sci. U. S. A. 2004, 101, 10470-10475. doi:10.1073/pnas.0403802101

12. Ceide, S. C.; Trembleau, L.; Haberhauer, G.; Somogyi, L.; Lu, X.; Bartfai, T.; Rebek, J., Jr. Proc. Natl. Acad. Sci. U. S. A. 2004, 101, 16727-16732. doi:10.1073/pnas.0407543101

13. Jantos, K.; Rodriguez, R.; Ladame, S.; Shirude, P. S.; Balasubramanian, S. J. Am. Chem. Soc. 2006, 128, 13662-13663. doi:10.1021/ja064713e

14. Tao, H.; Weng, Y.; Zhuo, R.; Chang, G.; Urbatsch, I. L.; Zhang, Q. ChemBioChem 2011, 12, 868-873. doi:10.1002/cbic.201100048

15. Singh, S.; Prasad, N. R.; Kapoor, K.; Chufan, E. E.; Patel, B. A.; Ambudkar, S. V.; Talele, T. T. ChemBioChem 2014, 15, 157-169. doi:10.1002/cbic.201300565

16. Szewczyk, P.; Tao, H.; McGrath, A. P.; Villaluz, M.; Rees, S. D.; Lee, S. C.; Doshi, R.; Urbatsch, I. L.; Zhang, Q.; Chang, G. Acta Crystallogr., Sect. D: Biol. Crystallogr. 2015, 71, 732-741. doi:10.1107/s1399004715000978

17. Shukla, S.; Abel, B.; Chufan, E. E.; Ambudkar, S. V. J. Biol. Chem. 2017, 292, 7066-7076. doi:10.1074/jbc.m116.771634

18. Pattenden, G.; Thompson, T. Chem. Commun. 2001, 717-718. doi:10.1039/b101417j

19. Singh, Y.; Sokolenko, N.; Kelso, M. J.; Gahan, L. R.; Abbenante, G.; Fairlie, D. P. J. Am. Chem. Soc. 2001, 123, 333-334. doi:10.1021/ja002666z

20. Singh, Y.; Stoermer, M. J.; Lucke, A. J.; Glenn, M. P.; Fairlie, D. P. Org. Lett. 2002, 4, 3367-3370. doi:10.1021/ol026463m

21. Sato, K.; Itoh, Y.; Aida, T. Chem. Sci. 2014, 5, 136-140. doi:10.1039/c3sc52449c

22. Sato, K.; Itoh, Y.; Aida, T. J. Am. Chem. Soc. 2011, 133, 13767-13769. doi:10.1021/ja203894r

23. Schnopp, M.; Ernst, S.; Haberhauer, G. Eur. J. Org. Chem. 2009, 213-222. doi:10.1002/ejoc.200800811

24. Comba, P.; Gahan, L. R.; Haberhauer, G.; Hanson, G. R.; Noble, C. J.; Seibold, B.; van den Brenk, A. L. Chem. - Eur. J. 2008, 14, 4393-4403. doi:10.1002/chem.200701778

25. Comba, P.; Dovalil, N.; Hanson, G. R.; Harmer, J. R.; Noble, C. J.; Riley, M. J.; Seibold, B. Inorg. Chem. 2014, 53, 12323-12336. doi:10.1021/ic5014413

26. Kay, E. R.; Leigh, D. A.; Zerbetto, F. Angew. Chem., Int. Ed. 2007, 46, 72-191. doi:10.1002/anie.200504313

27. Feringa, B. L.; Browne, W. R., Eds. Molecular Switches, 2nd ed.; Wiley-VCH: Weinheim, Germany, 2011. doi:10.1002/9783527634408

28. Erbas-Cakmak, S.; Leigh, D. A.; McTernan, C. T.; Nussbaumer, A. L. Chem. Rev. 2015, 115, 10081-10206.

doi:10.1021/acs.chemrev.5b00146
29. Qu, D.-H.; Wang, Q.-C.; Zhang, Q.-W.; Ma, X.; Tian, H. Chem. Rev. 2015, 115, 7543-7588. doi:10.1021/cr5006342

30. Rau, H. Angew. Chem., Int. Ed. Engl. 1973, 12, 224-235. doi:10.1002/anie.197302241

31. Mathews, M.; Zola, R. S.; Hurley, S.; Yang, D.-K.; White, T. J.; Bunning, T. J.; Li, Q. J. Am. Chem. Soc. 2010, 132, 18361-18366. doi:10.1021/ja108437n

32. Beharry, A. A.; Woolley, G. A. Chem. Soc. Rev. 2011, 40, 4422-4437. doi:10.1039/c1cs15023e

33. Bandara, H. M. D.; Burdette, S. C. Chem. Soc. Rev. 2012, 41, 1809-1825. doi:10.1039/c1cs15179g

34. Merino, E.; Ribagorda, M. Beilstein J. Org. Chem. 2012, 8, 1071-1090. doi:10.3762/bjoc.8.119

35. Natali, M.; Giordani, S. Chem. Soc. Rev. 2012, 41, 4010-4029. doi:10.1039/c2cs35015g

36. Wang, Y.; Urbas, A.; Li, Q. J. Am. Chem. Soc. 2012, 134, 3342-3345. doi:10.1021/ja211837f

37. Sun, R.; Xue, C.; Ma, X.; Gao, M.; Tian, H.; Li, Q. J. Am. Chem. Soc. 2013, 135, 5990-5993. doi:10.1021/ja4016952

38. Abendroth, J. M.; Bushuyev, O. S.; Weiss, P. S.; Barrett, C. J. ACS Nano 2015, 9, 7746-7768. doi:10.1021/acsnano.5b03367

39. Fihey, A.; Perrier, A.; Browne, W. R.; Jacquemin, D. Chem. Soc. Rev. 2015, 44, 3719-3759. doi:10.1039/c5cs00137d

40. Bisoyi, H. K.; Li, Q. Chem. Rev. 2016, 116, 15089-15166. doi:10.1021/acs.chemrev.6b00415

41. Glinsky-Olivier, N.; Guinchard, X. Synthesis 2017, 49, 2605-2620. doi:10.1055/s-0036-1589003

42. Griffiths, J. Chem. Soc. Rev. 1972, 1, 481-493. doi:10.1039/cs9720100481

43. Haberhauer, G.; Kallweit, C. Angew. Chem., Int. Ed. 2010, 49, 2418-2421. doi:10.1002/anie.200906731

44. Takaishi, K.; Kawamoto, M.; Tsubaki, K.; Furuyama, T.; Muranaka, A.; Uchiyama, M. Chem. - Eur. J. 2011, 17, 1778-1782. doi:10.1002/chem.201003087

45. Takaishi, K.; Muranaka, A.; Kawamoto, M.; Uchiyama, M. J. Org. Chem. 2011, 76, 7623-7628. doi:10.1021/jo201578z

46. Takaishi, K.; Muranaka, A.; Kawamoto, M.; Uchiyama, M. Org. Lett. 2012, 14, 276-279. doi:10.1021/ol203053q

47. Haberhauer, G.; Kallweit, C.; Wölper, C.; Bläser, D. Angew. Chem., Int. Ed. 2013, 52, 7879-7882. doi:10.1002/anie.201301516

48. Núñez, I.; Merino, E.; Lecea, M.; Pieraccini, S.; Spada, G. P.; Rosini, C.; Mazzeo, G.; Ribagorda, M.; Carreño, M. C. Chem. - Eur. J. 2013, 19, 3397-3406. doi:10.1002/chem.201203243

49. Adam, A.; Haberhauer, G. J. Am. Chem. Soc. 2017, 139, 9708-9713. doi:10.1021/jacs.7b05316

50. Mehrparvar, S.; Adam, A.; Haberhauer, G. Eur. J. Org. Chem. 2018, 4306-4316. doi:10.1002/ejoc.201800636

51. Haberhauer, G.; Pintér, Á.; Oeser, T.; Rominger, F. Eur. J. Org. Chem. 2007, 1779-1792. doi:10.1002/ejoc.200600942

52. Haberhauer, G. Angew. Chem., Int. Ed. 2007, 46, 4397-4399. doi:10.1002/anie.200605098

53. Becke, A. D. Phys. Rev. A 1988, 38, 3098-3100. doi:10.1103/physreva.38.3098

54. Lee, C.; Yang, W.; Parr, R. G. Phys. Rev. B 1988, 37, 785-789. doi:10.1103/physrevb.37.785

55. Miehlich, B.; Savin, A.; Stoll, H.; Preuss, H. Chem. Phys. Lett. 1989, 157, 200-206. doi:10.1016/0009-2614(89)87234-3

56. Grimme, S.; Antony, J.; Ehrlich, S.; Krieg, H. J. Chem. Phys. 2010, 132, 154104. doi:10.1063/1.3382344 
57. Grimme, S. Chem. - Eur. J. 2012, 18, 9955-9964. doi:10.1002/chem.201200497

58. Ditchfield, R.; Hehre, W. J.; Pople, J. A. J. Chem. Phys. 1971, 54 724-728. doi:10.1063/1.1674902

59. Hehre, W. J.; Ditchfield, R.; Pople, J. A. J. Chem. Phys. 1972, 56, 2257-2261. doi:10.1063/1.1677527

60. Schäfer, A.; Horn, H.; Ahlrichs, R. J. Chem. Phys. 1992, 97, 2571-2577. doi:10.1063/1.463096

61. Weigend, F.; Ahlrichs, R. Phys. Chem. Chem. Phys. 2005, 7, 3297-3305. doi:10.1039/b508541a

62. Gaussian 16, Revision A.03; Gaussian, Inc.: Wallingford, CT, 2016.

\section{License and Terms}

This is an Open Access article under the terms of the Creative Commons Attribution License

(http://creativecommons.org/licenses/by/4.0). Please note that the reuse, redistribution and reproduction in particular requires that the authors and source are credited.

The license is subject to the Beilstein Journal of Organic Chemistry terms and conditions: (https://www.beilstein-journals.org/bjoc)

The definitive version of this article is the electronic one which can be found at: doi:10.3762/bjoc.15.156 